\title{
GRIST SIZE DISTRIBUTION AND GELATINIZATION TEMPERATURE OF MALTED SORGHUM
}

\author{
BENJAMIN R. ETUK and SUNDAY E. OTU \\ (Received 17 June 2002; Revision accepted 22 August 2002)
}

\section{ABSTRACT}

The effect of particle size distribution of sorghum malt grist on gelatinization temperature of the sorghum mash was assessed with respect to sorghum variety ICSV400. This was with a view to determining the possible relationship between the grist size distribution and the temperature at which the mash from such grist will gelatinize. Sorghum grist size distribution was determined by sieve analysis after milling the malt samples at different periods of time. The initial gelatinization temperatures of samples containing a higher proportion of fine and flour particles were lower than samples with more of the coarse particles, but the gelatinization of all the samples occurred within the temperature range of $70^{\circ}-75^{\circ} \mathrm{C}$.

Key words: Grist size distribution, gelatinization temperature, sorghum malt, mashing

\section{INTRODUCTION}

The process of brewing conventional beer from the malted form of cereals such as barley, and sorghum varieties has been practised the world over, the latter being quite successful with the use of external enzymes (Briggs, et. al. 1971; Palmer, 1983; Aisien \& Mutts, 1987; Okon, 1995). Other cereals such as maize, rice, wheat and rye are usually added as adjuncts in the form of grist, grit, flours, refined starches, sucrose and invert sugars (Palmer, 1983).

One of the steps during the brewing process is the mashing process whose goal is to obtain the highest possible yield of extract of the highest possible quality from the malt grists and adjuncts by extraction in the brewing water (Briggs, et. al. 1971; Alfa-Laval, 1982).

In mashing, when the ground malt is mixed with water usually containing salts many, interrelated biochemical and physical changes begin and proceed simultaneously. These changes result in four important processes, namely, hydrolysis, gelatinization, liquefaction and saccharification (Briggs, et. al. 1971; Palmer, 1983), which enable the enzymes to do their jon at their maximum ability in order to achieve the maximum conversion of the insoluble raw materiuls for maximum extract production (Alfa-Laval 1982).

Starch is one of the components of grists which is broken down during mashing by the amylase enzymes to maltose, dextrins, and other sugars (Alfa-Laval). Two types of starch in the mash are identified and these are the amylose and amylopectin, which differ in their properties when heated (Lineback 1997). According to the literature (Alfa-Laval, 1982; Palmer, 1983; Lineback, 1997; Briggs et. al., 1971) the starch molecules of grist are insoluble in cold water. In warm water, however, they start to absorb water and swell. A certain temperature is reached at which the granules have grown big enough that they start rubbing against one another. The rubbing action produces a leaching effect on the cell-wall materials especially when there is stirring taking place. which is normally the case. The leaching continues until the cell-wall materials are broken down completely. At this point, the mash becomes viscous and thick and is said to be gelatinized. This physical process which is cailed gelatinization usually occurs within a range of temperature referred to as the gelatinization temperature. According to Palmer (1983), the amylopectin which forms the gel when heated is attacked by beta-amylase which is an exoenzyme, to produce mainly maltose and large moleculer weight dextrins called beta-dextrins, while the alpha-amylase attack causes a reduction in starch viscosity, thus increasing the solubility of the starch and sugar products such as glucose, maltose and alpha-limit dextrins which are produced. Attack on the ungelatinized starch granules is said to be low, (raw starch is attacked by alpha-amylase slowly and by betaamylase not at all). Therefore gelatinization is necessary during mashing because the loss of birefringence and crystallinity at the branching points of amylopectin creates a conducive atmosphere for the amylase to attack the starch 
and produce sugars capable of being metabolised by yeast during fermentation (Hough et. al., 1982).

Palmer (1983) reports that the optimal temperature for beta-amylase is $62^{\circ}-65^{\circ} \mathrm{C}$, which is suitable for barley malt. However for scrghum mash, gelatinization temperature is within the range of $69^{\circ}-75^{\circ} \mathrm{C}$, while for some varieties it can be as high as $80^{\circ} \mathrm{C}$ (Jayatissa, et. al., 1980); and this favours the activity of alpha-amylase for the production of more glucose and maltose.

The high gelatinization temperature of sorghum plus the fact that it is sometimes used as grit illustrate why it is cooked before being added to the mash tun as against barley which can be added without prior gelatinization to a conventional mash tun which stands at $65^{\circ} \mathrm{C}$.

Although the level of the starch hydrolysing amylases which develop in sorghum during malting is low when compared with those of barley malt (Etokakpan and Palmer, 1992; Agu \& Palmer 1997(b)), comparable extract yields were obtained when adapted mashing procedure was used, which gelatinized sorghum starch and protected its enzymes (Agu \& Palmer 1997(a)).

In a conductive heat transfer through solid particles, the temperature change is proportional to the thermal resistance of the particles which is a function of the thickness of the particles, area through which heat is flowing and thermal conductivity of the particles (Baker, 1983). During the mashing process, heat transfer by conduction predominates through the grist particles. Also, since the thermal conductivity of the grist materials can be assumed to remain the same, the temperature change within the particles should therefore depend on the area fur heat transfer, which is a function of the size of the particles.

In this study, the effect of the grist size distribution on the temperature at which malted sorghum mash gelatinizes is assessed. This is with a view to determining the possible relationship between the grist size and temperature at which the mash from such grist will gelatinize.

\section{EXPERIMENTAL}

\section{Sorghum Grain}

The sorghum samples of variety ICSV400 used for this study were obtained from the Institute of Agricultural Research. Ahmadu Bello University, Zaria. The samples were analysed for viability and moisture content according to the Recommended Methods of Analysis (IOB, 1986).

\section{Malting Procedure}

The experimental malt was prepared from the grain sample by the method described previously (Etuk et. al., 1999). The malt sample so prepared was analysed for malting loss (IOB, 1986; EBC, 1977) before storage.

\section{Milling Process}

About $120 \mathrm{~g}$ of the malted sorghum grains were each milled using the manual grinder and Eiectric blender (Beltone Minshuil Model). With the electric blender the malt samples were each milled for 5,10 and 45 minutes to give samples 1 3 respectively, while with the manual grinder, samples 4 and 5 were obtained for grains milled for 20 and 30 minutes respectively. All milling experiments were done in triplicates.

\section{Particle Size Analysis of Milled Samples}

The method used to analyze the particle size distribution of the milled samples of the sorghum malt was the same as recommended by Tyler (1973) and described previously (Okon and Etuk, 1992). The fraction retained on or passing through each sieve was weighed and reported as per cent of total grist.

\section{Mashing and Determination of Gelatinization Temperature}

The decoction method (EBC, 1977; Aisien, 1991) was used with some modifications for the mashing procedure. Exactly $100 \mathrm{~g}$ of the grist sample was added to $400 \mathrm{ml}$ of distilled water in a beaker at $45^{\circ} \mathrm{C}$ and stirred thoroughly with a glass rod to prevent the formation of lumps. The mash beaker was placed in a thermostatic water bath and the temperature of $45^{\circ} \mathrm{C}$ in the mash was maintained for 30 minutes with continuous stirring. After this time interval, the temperature was raised by $1^{\circ} \mathrm{C}$ a minute for about 25 minutes with continuous stirring until gelatinization of the mash was observed. At the point when the mash started showing gelling nature, the temperature of the mash was further raised, the mash becoming thicker until a point was reached where it started liquefying, which marked the end of the gelatinization process. The gelatinization temperature (range) of the sample was then recorded as that at which the mash started gelatinizing and the one at which the mash started liquefying. This procedure was repeated for all the grist samples in duplicates. 


\section{RESUSLTS AND DISCUSSION}

\section{Grain Analysis}

The results of the viability test and composition analysis for the sorghum sample used in the study are given in Table 1, and these confirm that the grains were viable with adequate moisture content, hence suitable for malting and brewing.

\section{Particle Size Analysis}

The particle size distribution of the five samples plotted as percent passing through against average particle size is presented in Figure 1.
These results which are summarised in Table 2 show that Samples 1 and 4 contain more of the coarse particles while Samples 2 and 5 contain more of the fine particles. More flour particles is, however, contained in Sample 3. These variations in the particle size distribution may be attributed to the milling efficiency of the system and power applied during the process.

\section{Gelatinization Temperature}

The gelatinization temperature of Samples 2 and 5 which contain almost the same proportion of coarse, fine and flour particles ranged from $71^{\circ} \mathrm{C}$

Table 1: Proximate Analysis of Sorghum Grain (Variety ICSV400)

$\begin{array}{ll}\text { Moisture Content (\%) } & 9.8-10.6 \\ \text { Germinative Energy (\%) } & 99.0 \\ \text { Germinative Capacity }(\%) & 100.0\end{array}$

Table 2: Particle Size Distribution of Malted Sorghum (Variety ICSV400)

\begin{tabular}{l|l|l|l}
\hline \multirow{2}{*}{ Somples } & \multicolumn{2}{|c}{ Fractional Particle Size Distribution (\%) } \\
\cline { 2 - 4 } & Coarse & Fine \\
& $2000-600 \mu \mathrm{m}$ & $600-75 \mu \mathrm{m}$ & $\begin{array}{l}\text { Flour } \\
-75 \mu \mathrm{m}\end{array}$ \\
\hline & & & \\
1 & 50.1 & 39.9 & 10.0 \\
2 & 28.6 & 54.4 & 17.0 \\
3 & 17.6 & 36.1 & 46.3 \\
4 & 50.8 & 42.2 & 7.0 \\
5 & 28.1 & 56.2 & 15.7 \\
\hline
\end{tabular}

Table 3: Gelatinization Temperature of Malted Sorghum Grist (Variety ICSV400), with Varying Particle Size Distrilzution.

\begin{tabular}{l|r|r|r|c}
\multirow{2}{*}{ Samples } & \multicolumn{3}{|c|}{ Grist Proportions(\%) } & Gelatinization Temperature \\
& \multicolumn{2}{|c|}{${ }^{\circ} \mathrm{C}$} \\
\hline & Coarse & Fine & Flour & \\
\cline { 2 - 4 } 1 & 50.1 & 39.9 & 10.0 & $72-75$ \\
2 & 28.6 & 54.4 & 17.0 & $71-74$ \\
3 & 17.6 & 36.1 & 46.3 & $70-74$ \\
5 & 50.8 & 42.2 & 7.0 & $73-75$ \\
& 28.1 & 56.2 & 15.7 & $71-73$ \\
\hline
\end{tabular}




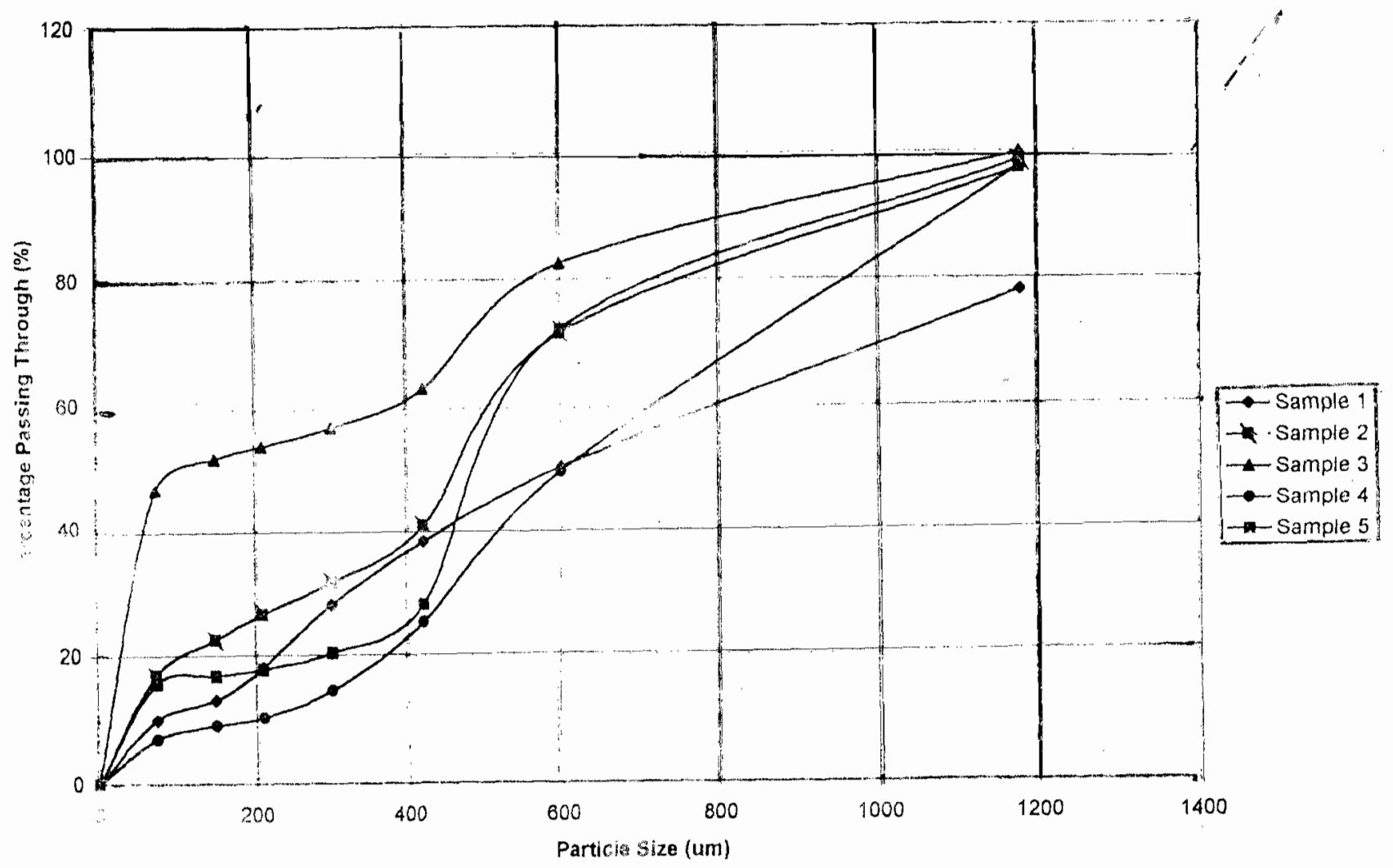

Fig. 1: Particle Size Distitition of Sorghum Malt Grist (Sorghum Varicity ICSV 400)

to $74^{\circ} \mathrm{C}$, while that for Sample 1 and 4 with higher proportion of the coarse particles ranged from $72^{\circ} \mathrm{C}$ to $75^{\circ} \mathrm{C}$. A slightly higher initial gelatinization temperature for Sample 4 was observed and this may be attributed to the cumbined effect of the coarse and fine proportions of the malt particles. Generally, with higher proportions of the flour particies, a decrease in the initial gelatinization temperature of the samples was observed, and this increased with increase in the coarse proportions. However, for all the samples, the gelatinization temperature ranged between $69^{\circ} \mathrm{C}$ and $75^{\circ} \mathrm{C}$ as earlier reported for sorghum (Hough, et. al., 1982; Palmer, 1983).

\section{CONCLUSION}

These results show clearly that the rate of heat transfer hence the temperature change within the particle, in the mash depends on the particle size distribution of the grist. This effect manifests itself in the initial gelatinization temperature of the mash, which increases with an increase in the coarse proportion of the particles but decreases with an increase in the proportions of the flour particles in the grist.

\section{REFERENCES}

Agu, R.C. and Paimer, G.H., 1997a. Filleet of mashing procedures on some sorghnm varrictios germinated at different temperatures. Process Biochemistry, $30(2) ; 147-158$.

Agu, R.C. and Palmer, G. H., 1997b. The eflect of temperature in the modification of sorghum and barley during malting Process Biochemistry, 32(6); $501-506$.

Aisicn, A. O., 1991. Sorghum - Malting and brewing polentials. Paper presented at the Brewing Seminar on auxilliary enzymes in the brewing industry, Lagos, Nigeria.

Aisien, A. O. and Mutls, G. C. J., 1987. Micro-scale malting and brewing studies on some sorglum varieties, $J$. Inst. Brew, 93: 328-331.

Alfa-laval, 1982. Brewing Handbook. Brewing and Fermentation. Alfa-Laval Separation Division. Tumba, Sweden.

Baker, A. J., 1983. Materals handing and size reduction. [n: Introduction to Brewing Science and Technology, Part 111. Rainbow, $C$ and Hoan, (i. I: S. eds. Institute of Brewing, London. pp. $110-112$ 
Briggs, D. E., Hough, J. S., Stevens, R. and Young, T. W., 1971. Malting and Brewing Science, Vol. 1, Chapman and Hall, London. pp 89-110.

E.B.C., 1975. Analytica-EBC, $3^{\text {rd }}$ edn. Schweizer BrauerRundschau, Zurich.

Etokakpan, O. U. and Palmer, G. H., 1992. Comparative studies of the development of endospermdegrading enzymes in malting sorglum and barley. World J. Microbiol. and Biotech, 6:408-417.

Etuk, B. R., Abuajah, C. I. and Ogbonna, A. C., 1999. Effect of drying temperature on the malting characteristics of an improved sorghum variety, GJPAS, 5(3): $327-330$

Hough, J. S., Briggs, D. E., Stevens, R. and Young, T. W., 1982. Malting and Brewing Science, Vol.II, Clrapman and Hall, London. pp 456-494.

IOB, 1986. Recommended Methods of Analysis. Institute of Brewing. London.

Jayatissa, P. M., Pathirans, R. A. and Sivayogasun, K., 1980. Malting quality of Sri Lankan varieties of sorghum, J. lost. Brew $86 \cdot 18.7 n$
Lineback, D. R., 1997. Starch. In: Encyclopedia of Science and Technology, Vol.17. McGraw-Hill Limited, N.Y. pp 331-333.

Okon, E. U. 1995. Potential mashing regimes in sorghum wort production: The Nigeria experience. Inst. Brew., Proc. $5^{\text {th }}$ S.A. Sect., Victoria Falls. Zimbabwe. pp 97-105.

Okon, E. U. and Euk, B. R., 1992. The evaluation of milling performance of malting sorghum as a modification index. Nigerian Food J., 10: 70-76.

Palmer, G. H., 1983. Malting and Mashing. In: Introduction to Brewing Science and Technology, Part 1. Rainbow, C. and Float, G. E. S., eds., Institute of Brewing, London. pp 10-27.

Tyler, W. A., 1973. Testing Sieves and their Uses. In: Handbook 53, Tyler Inc., U. S. A. pp 5-9. 